\title{
MOTIVOS DE ASSOMBRAÇÃO E RUÍNA: MURILO MENDES E OURO PRETO
}

George França

Mestrando em Literatura - UFSC

Resumo: O texto performa um enigma a partir da publicação, em 1951, na revista Anhembi, do ainda inédito Motivos de Ouro Preto, que depois comporia o volume Contemplação de Ouro Preto, publicado em 1954 através do Serviço de Documentação do Ministério da Educação e Cultura. A edição sob auspício governamental, somada ao fato de que o volume vem ilustrado por fotos de Humberto Moraes Franceschi e Erich Hess, nos leva a pensar as relações já adiantadas do Modernismo com o Estado no sentido da preservação do patrimônio. O poema se inscreve, junto com outras imagens, portanto, na documentação e na transformação das forças da torção barroca em formas. Trata-se, pois, de investigar as relações entre um modernista, o Estado e o Barroco mineiro, para propor, a partir daí, uma leitura a contrapelo, que encontre, dentro de uma obra facilmente identificável ao autonomismo, os espectros que o assombram e, assinalando a morte de Deus (e por conseguinte dos valores absolutos), problematizem as leituras estatais dessa produção documental, turística e patrimonializadora dentro da poética muriliana.

Palavras-chave: Murilo Mendes; Modernismo; Barroco.

Abstract: This text performs an enigma based in the first publication of the poem Motivos de Ouro Preto in 1951 at the Brazilian review Anhembi. After, the poem was included in the book Contemplação de Ouro Preto, published in 1954 by the Documentation Service of the Brazilian Ministry of Education and Culture. The edition under government auspice, and the fact that the book was illustrated with photographs by Humberto Moraes Franceschi and Erich Hess make us think about the advanced relations between Modernism and State for the patrimony's preservation. The poem inscribes itself, with other images, therefore, in the documentation proceedings and in the transformation of baroque torsion forces into forms. The essay tries to brush these texts against the grain and find, inside a work easily identifiable to autonomism, the specters that haunts it and, marking God's death (and consequently the death of the absolute principles), entangle the statal reading of this documental, tourist, and patrimonialist production inside Murilo Mendes' poetic.

Keywords: Murilo Mendes; Modernism; Baroque. 
De forma geral, não me detenho muito nessas recordações. Passados tantos anos, já perderam o poder de me afetar: o tempo neutralizou-as. Só puderam recobrar vida deformadas, irreconheciveis e ganhando, no decorrer de sua transformação, um sentido obsceno.

(Georges Bataille, História do olho)

Motivo: não puramente propulsão racional, mas busca indômita. Motivo também como imagem que assom(br)a, como pedra, aporia que se interpõe no caminho. Recupere-se a pulsão para escovar o passado a contrapelo. A viagem não só como distanciamento, mas também como laceração. É possível narrar apenas como reficcionalização, errônea, falha e deliberada. Como procurar a origem sem a obsessão da gênese? Que devir das forças encontraria nas ruínas ao viajar nos olhos de outro viajante, quase sessenta anos afastado? $\mathrm{O}$ espectro pode falar mais que a pedra? Poderia o espectro falar? O que há na pedra, que muda e prismática se oferece ao olho? O patrimônio é morte ou pervivência? E que outra ruína muda se poderia armar com uma colagem de cacos?

\section{(De)pensar}

No recente Politique de la littéreture (2007, p.29), Jacques Ranciére caracteriza o mundo moderno da seguinte forma:

um vasto tecido de signos, de ruínas e de fósseis que assimilam a poesia nova, a poesia da prosa do mundo, ao trabalho dos filólogos, arqueólogos ou geólogos. Mas ele é também um mundo repovoado de criaturas fantásticas instaladas por trás de todas as fachadas ou escondidas atrás de todas as grandes portas por onde passam os carros, de novas divindades da terra e dos infernos. ${ }^{1}$

Remissivamente, podemos aqui tocar Benjamin, em cujos escritos nos deparamos com a modernidade como acumulação de fragmentos e de ruínas, documentos da cultura como barbárie, conforme as conhecidas teses Sobre o conceito de história. Ora, Benjamin foi leitor de Baudelaire, em cujas Correspondances encontramos um homem que passa através de uma floresta de símbolos, na qual os fragmentos doutros e desses tempos lhe dirigem olhares, e mais, estabelecem entre si uma conversa em que os ecos se confundem, não havendo comunicação, mas sentidos que se correspondem numa conversa infinita, sem objeto e sem univocidade.

Para Ranciére, essa mesma perda da univocidade (diga-se: da autoridade e do domínio sobre a significação, radicalização de uma potência democrática da linguagem) permite que a literatura estabeleça uma nova política, não da ordem da disputa pelo poder, mas da transformação do que o autor denomina "partilha do sensível". Esta seria a "distribuição e a redistribuição dos espaços e dos tempos, dos lugares e das identidades, do discurso e do ruído, do visível e do invisível." (RANCIÉRE, 2007, p.21) O objeto literário, assim, conjugaria dois regimes de significação: o ordinário, prosaico, e o intransitivo, sem objeto, com fim em si mesmo. $\mathrm{O}$ assalto desse segundo regime ao primeiro, politicamente lido como aristocrático (torres de marfim e afins) por Sartre, seria uma "petrificação da linguagem". Entretanto, Ranciére procura desfazer o vínculo negativo dessa relação da literatura com a pedra ao ver nela uma forma de supressão da hierarquia, um "igualitarismo radical". A literatura se torna, assim, comparável a uma pedra muda. "Seu mutismo tagarela revoga a distinção entre os homens do discurso de ação e os homens da voz doente e ruidosa, entre aqueles que agem e aqueles que não fazem senão viver." (ibid., loc. cit.) 
Por essa ordem da literatura da marca, que recupera outra potência de significação da linguagem, de afecção sensível (em palavra cara não só a Ranciére, mas também a Deleuze como leitor de Spinoza), marca-se, de partida nessa (re)vi(s)agem, uma leitura da ordem da busca de alguma verdade das coisas "à maneira pela qual os fósseis ou as estrias da pedra portam sua história escrita." (ibid., p.23) Ao perquirir a visitação de Murilo Mendes às pedras de Ouro Preto, ao reino patrimonializado da pedra, ao ler esses testemunhos literários como outras pedras vincadas pela história, busco, pois, uma relação de signo a signo em que o testemunho das coisas mudas se inscreve na linguagem. Pois "o escritor [e aqui também aquele que exerce o ato ficcional do crítico] é o arqueólogo ou o geólogo que faz falar os testemunhos mudos da história comum." (ibid., p.24) É nessa dobra da marca da morte, nessa imagem inscrita e pervivente pelos tempos, nessa clave de leitura que adentro a Ouro Preto de Murilo Mendes, poeta-geólogo que reconstrói das ruínas uma cidade, arrancando à pedra muda "o segredo dos primeiros tempos de sua história." (ibid., p.25)

É certo que o movimento teórico de Ranciére não é solitário. A idéia de procurar essa marca de uma história, de uma origem nos espólios da cultura pode ser alcançada já no Benjamin de A origem do drama barroco alemão, especialmente no tratamento que dá à idéia de origem. Não se trata, com efeito, em suas perquirições teóricas, de encontrar a gênese, o ponto a partir do qual se daria a evolução linear de determinado fenômeno no campo da cultura. A origem benjaminiana concerne à pré e à pós-história das idéias, em seu caráter inconcluso e imperfeito. Uma obra de arte contém em potência todas as outras: essa premissa orienta a leitura do drama barroco alemão de Benjamin. Peça rejeitada até então pela crítica, como menor, o Trauerspiel (drama barroco alemão) é chave para a elaboração de uma teoria que concerne também ao presente, através das ditas conexões essenciais, do anacronismo. A isso podemos somar as reflexões de Deleuze, em Spinoza e as três "éticas" (no volume Crítica e clínica), no qual o filósofo francês considera que um signo pode ter vários sentidos, mas é sempre um efeito, um vestígio de um corpo sobre outro, uma affectio: uma marca de um devir, de uma passagem, de uma ascensão e queda. "Os afectos são sempre afecções de onde derivam" (DELEUZE, 1997, p.158), sendo estas forças variações de potência que conduzem à leitura para além das formas, cristalizadas, com que se trabalharia na lógica de Estado.

Dessa forma, ao ensaiar uma fala sobre um poema de Murilo, ou sobre a arquitetura barroca mineira, também se trata de problemas que pervivem: o da patrimonialização engendrada pelo próprio modernismo em sua feição marioandradina, o do Estado e da transformação das forças em forma.

\section{Uma assombração: o Estado}

A anacronização de Ouro Preto realizada por Murilo Mendes pode ser inscrita nesse procedimento de découpage do mundo através da linguagem, no caso, de uma linguagempedra que também trata da pedra, no caso, da pedra-monumento: a arquitetura barroca mineira do século XVIII. Dirijo-me, aqui, especificamente ao enigma que parte da publicação, em 1951, na revista Anhembi, do ainda inédito Motivos de Ouro Preto, que depois comporia o volume Contemplação de Ouro Preto, publicado em 1954 através do Serviço de Documentação do Ministério da Educação e Cultura. A publicação sob auspício governamental, somada ao fato de que o volume vem ilustrado por fotos de Humberto Moraes Franceschi e Erich Hess, nos leva a pensar as relações já adiantadas do Modernismo com o Estado no sentido da preservação do patrimônio. O poema se inscreve, junto com outras imagens, portanto, na documentação e na transformação das forças da torção barroca em formas. Entretanto, essas mesmas forças acabam se manifestando ao longo dos poemas de 
Murilo nesse livro, assombrando pelas ruínas uma inscrição estatal. Vale a nota de que Hess participou do projeto da Obra Getuliana, ideado por Capanema para documentar os feitos de Getúlio Vargas em seus dez primeiros anos de governo. Aline Lopes de Lacerda, pesquisadora da FGV, dá conta dessas informações, bem como do fato de que o livro nunca foi publicado, mas que seu projeto, várias vezes reformulado por Capanema, resultou na compilação de seiscentas fotografias-documentário-propaganda dos feitos do ditador. A orientação era fotografar, segundo depoimento do próprio Erich Hess (a quem coube fotografar o Sul do Brasil), “Tudo, menos a miséria! Quando nós fomos mandados, nós fomos mandados para ver as coisas bonitas que ele fez... eu não recebi uma indicação de 'faz só o que é bonito', mas estava claro que a gente escolhia o aspecto." (HESS, apud LACERDA, 1994, p.250)

Esse aspecto bífido de inscrição do livro de poemas (por um lado, nada convencional ou laudatório, por outro, com subvenção estatal à guisa de roteiro patrimonial) passa também pela idéia da viagem. O livro é datado, ao final, como escrito em "Ouro Preto - Mariana Rio, 1949-1950". Júlio Castañon Guimarães dá conta de que o livro foi o último escrito antes da partida de Murilo para a Europa, que, em sua produção, marcaria a visita anacrônica a outras ruínas: as da Sicília e as da Espanha (Siciliana e Tempo espanhol). Guimarães ainda trata essa faceta da produção de Murilo como uma empreitada de tematização cultural, e ressalta que é tentador procurar traços barrocos na Ouro Preto de Murilo graças ao tema, mas que esses traços não estão ali em sua maior vivacidade. Ainda que eles possam ser lidos em toda a produção de Murilo, "nas imagens antinômicas e dilaceradas com que se travam os embates da religiosidade", a Contemplação caracteriza-se, a seu ver, por uma "postura diretamente descritiva, que se perfaz muitas vezes numa enumeração acumulativa" (GUIMARÃES, 1986, p.66). Não estaria, entretanto, nessa mesma acumulação um procedimento barroco, um excesso, uma dobra da cidade na poesia, uma dobra da poesia sobre a cidade? Ao lado de uma enumeração da arquitetura, dos ritos e das ladeiras de Ouro Preto, surgem também os objetos que se inscrevem na paisagem pelo olhar, pela linguagem do poeta que observa: os espectros, os mortos, as pervivências, as marcas na pedra.

\section{Os motivos e a viagem}

Como disse, a Contemplação de Ouro Preto se abre com os Motivos de Ouro Preto. Um motivo pode ser uma causa, uma razão; mas, derivando do latim motu, forma do verbo movere, motivo é também um móvel, e o poema passa a ser a posta em cena, então, do que move o poeta à ruína barroca, ou do que se move dentro dela. Nesse caso, o motivo é interior, e não exterior, produzindo objetos que são efeitos sem causa aparente, unindo objeto ordinário a um aspecto novo de intransitividade, com isso dobrando a lógica casuística da modernidade ${ }^{2}$. Motivo é ainda uma frase musical recorrente, ou, com Houaiss e Villar (2001), o "tema, idéia etc. (freqüentemente expressa em desenho, imagem etc.) principal e/ou recorrente que, numa obra de arte, estabelece um padrão". Ou seja, atravessando-se a primeira portada do livro, estamos frente a um objeto que entrecruza linhas de todos os outros ali dentro. Uma leitura cruzada, pois, se mostra elucidativa.

O poema vem dedicado a Rubem Navarra, crítico de artes plásticas que colaborou, inclusive, com a Revista Acadêmica de Murilo Miranda, e se liga, assim, ao grupo dos modernistas e a revistas próximas de Anhembi. Nas dedicatórias dos poemas do livro, há ainda espaço para Manuel Bandeira, autor, também, de um Guia de Ouro Preto, publicado em 1938. Essa idéia de turismo e de viagem em relação ao patrimônio barroco mineiro (Murilo, então radicado no Rio, também fala do Ouro Preto em viagem) pode outrossim remeter a Mário de Andrade e a duas visitações da cidade. Primeiramente, a de 1919, que resulta na publicação de 
textos na Revista do Brasil, que também foram conferência realizada na Congregação de Santa Efigênia. Nesta, aparece já a preocupação de Mário com encontrar o nacional na mirada àquelas manifestações artísticas que primavam, a seu ver, pelo decorativo, aproximando-se da arquitetura romana em detrimento da "nobre unidade estética" grega ou gótica. Para o Mário de 1919, o barroco possui

a circunstância pejorativa de ser nele a própria decoração que determina o estilo. Ora, na arquitetura religiosa de Minas a orientação barroca - que é o amor da linha curva, dos elementos contorcidos e inesperados - passa da decoração para o próprio plano do edifício. Aí os elementos decorativos não residem só na decoração posterior, mas também no risco e na projeção das fachadas, no perfil das colunas, na forma das naves.

Com esse caráter assume a proporção dum verdadeiro estilo, equiparandose, sob o ponto de vista histórico, ao egípcio, ao grego, ao gótico. E é para nós um motivo de orgulho bem fundado que isso tenha se dado no Brasil. (ANDRADE, 1993, p.79-80)

Nessas anotações de um Mário que ainda não é o papa do Modernismo, anteriores mesmo ao acontecimento da Semana de 22, aparecem duas preocupações em relação ao Barroco, que desviam o que seria um foco que nos levaria à força e ao Expressionismo ${ }^{3}$, influxo notado no destaque dado à contorção e ao inesperado. A primeira delas é a da homogeneidade de um estilo que não pode conter excesso, ou da narrativização das forças que as transforma em formas. A segunda é a afirmação do nacional, da contribuição brasileira à conformação de um estilo verdadeiro, da denegação do caráter de puramente importado ou assimilado.

Por outro lado, outra viagem merece remissão nesse momento: a já clássica viagem em que Blaise Cendrars foi ciceroneado pela comitiva chefiada por Mário, Oswald e Tarsila para conhecer essas mesmas (outras) Minas Gerais. Silviano Santiago, notando $A$ permanência do discurso da tradição no modernismo, recupera uma observação interessante de Brito Broca sobre o chamado dessas "antiguidades" para os então iconoclastas vanguardistas:

Parecia um contrasenso apenas aparente. Havia uma lógica interior no caso. O divórcio em que a maior parte dos nossos escritores sempre viveu da realidade brasileira fazia com que a paisagem de Minas barroca surgisse aos olhos dos modernistas como qualquer coisa de novo e original, dentro, portanto, do quadro de novidade e originalidade que eles procuravam. E não falaram, desde a primeira hora, numa volta às origens da nacionalidade, na procura de um filão que conduzisse a uma arte genuinamente brasileira? Pois lá nas ruínas mineiras haviam de encontrar, certamente, as sugestões dessa arte. (BROCA, apud SANTIAGO, 2002, p. 121)

Se, por um lado, partiram dessa viagem estímulos a uma produção diferenciada, como afirma Brito Broca, ou seja, se por um lado a visitação funcionou como motivo, por outro, essas visões também revertem na consolidação de uma matriz de entendimento do patrimônio nacional (e da idéia autonomista de nação) que hipertrofiza o arquitetônico, a pedra em si, e especialmente a arquitetura barroca mineira. Aqui assoma o nome de Rodrigo Mello Franco de Andrade, diretor do Serviço do Patrimônio Histórico e Artístico Nacional e diretamente ligado a Mário. A Rodrigo, na Contemplação de Ouro Preto, vai dedicado o Romance das igrejas de Minas; a Graciema M. F. de Andrade, esposa do diretor nomeado por Capanema, o poema Sacristia do Carmo de Ouro Preto; respectiva e simetricamente, a segunda e a penúltima parte do volume. Capanema também recebe a dedicatória de um dos poemas: o das Luminárias de Ouro Preto, ou seja, o que a ele 
remete é a luz, ou, por outra via, a razão, o projeto racional de construção de um Estado que pudesse corresponder a certa idéia de nação. Os nomes de Rodrigo, de Capanema e de Lúcio Costa estão no fulcro da criação de um passado artístico paradigmático para o Brasil dentro do Estado Novo, centrado nas formas da arquitetura mineira e na canonização desse espaço. Por outro lado, surgem impasses quando ocorre a reforma do Liceu de Artes e Ofícios para abrigar o Cine Vila Rica, ou ainda, quando Lucio Costa e Oscar Niemeyer decidem construir um hotel de feição totalmente moderna em pleno espaço da arquitetura colonial. De acordo com Carolina Cantarino (2005), em leitura, na Patrimônio, publicação online do Iphan, da dissertação de mestrado de Evelyn Meniconi a respeito do assunto, graças à solução encontrada para o cinema (algo moderno por excelência implantado no meio da ruína barroca),

A cópia das antigas construções coloniais visando a manutenção do estilo barroco da arquitetura da cidade torna-se, então, recorrente. Mas uma solução para se evitar esse tipo de falseamento já havia sido proposta por Lúcio Costa e Oscar Niemeyer através da construção do Grande Hotel, a partir de 1939. Para esses modernistas, na medida em que o barroco colonial seria o verdadeiro passado da moderna arquitetura brasileira, haveria uma continuidade entre eles. Nesse sentido, os monumentos de Ouro Preto, segundo Lúcio Costa, poderiam conviver, lado a lado, com construções modernas da chamada "boa arquitetura".

\section{A assombração da ruína}

Entrarei agora mais detidamente na análise do poema. A transcrição coteja a maneira como foi publicado em Anhembi com a edição de 1954, o volume Poesias, coletânea organizada por Murilo Mendes em 1959, e a obra completa editada pela Nova Aguillar.

\section{Motivos de Ouro Prêto}

Assombrações que sobem do barroco

Das ladeiras e dos crucifixos esquálidos,

Frias portadas de pedra, anjos torcidos,

Passantes conduzindo aos ombros o passado,

Cemitérios aéreos de adros largos

Onde noturnos seresteiros cantam,

Seguindo-se de violas e violões,

Aos defuntos colados nas gavetas:

A experiência de sombras trasladadas

De procissões civis, eclesiásticas,

De antigo túnel de conspiração,

A água escapando pelos chafarizes,

As cicatrizes que o minério abriu,

Tantos Passos fechados o ano inteiro,

Ruinas de solares e sobrados

Onde pairam espectros de poetas,

De padres doidos, de reformadores;

Algarismos gravados nas carrancas,

A presença do tempo traduzindo,

O silêncio ao silêncio se juntando

Anuário de Literatura v. 13, n. 1, 2008, p. 79 
Nesses becos e vielas embuçados,

A reunião de natureza e arte

Por um gênio severo combinadas,

O espirito levando à sua origem

Despojado de efêmeros enfeites, ${ }^{4}$

A pátina paciente de Ouro Prêto

Sôbre aparências estendendo um véu:

Tudo aparelha a mente para a morte,

Mas a morte em si mesma, a própria morte,

Privada de artificio, a morte chã. ${ }^{5}$

E contra a dispersão das ossadas no tempo, Que o amor à forma e a Promessa repelem ${ }^{6}$, Da pedra o testemunho antigo se levanta,

Poder do Itacolomi - e o da pedra perene.

\section{2}

O canto alternativo das igrejas

Nos leves sinos da levitação

Cruzando-se em cerrado contraponto,

São Francisco de Assis adverte ao Carmo,

São Francisco de Paula à matriz do Pilar.

Devolve o ar ao ouvido o som das campainhas

Dessas humildes mulas pensativas

Que parecem voltar da Palestina.

E êsses pianos dir-se-iam pianolas

Tangendo sons remotos, subterrâneos,

Restos de roídas polcas e mazurcas...

Pianos inconfidentes.

Cindem o ar sêco, poroso,

Pancadas pacientes de relógio.

$\hat{E}$ sse vago clarim nos longes do quartel

Atende ao ido apêlo de outro tempo:

Erra insatisfeita nos ares

A alma trágica do alferes

Joaquim José da Silva Xavier.

Os amigos chamou, e o eco respondeu...

A Viúva de Ouro Prêto sobe a rua cantando, Apoiada ao bastão, na cabeça um penacho De três côres, vestido velho e desbotado Cuja invisivel cauda arrasta com desdém. A Viúva de Ouro Prêto fala em frases cifradas, Pesa em partes iguais o mito e a realidade, O passado e o presente, a alegria e a tristeza, Declara que decide a guerra no estrangeiro, Rico e pobre entretém com igual polidez. A trama da sua vida é feita de fantasmas Que só se extinguirão no seu último dia: A Viúva de Ouro Prêto desce a rua rezando ${ }^{7}$. 
Que possuiu fazenda, escravos e palácios,

Privou com a Imperatriz, refinou-se na Europa,

Serviu banquetes em baixelas persas,

Depois tudo perdeu, os membros dispersou,

Resta Dona Adelaide Mosqueira de Menezes,

Vítima da jogatina, a Viúva de Ouro Prêto

Que vive numa toca de espectros rodeada,

Que inda tem uma pedra onde apóia a cabeça...

A Viúva de Ouro Prêto é de grande família ${ }^{8}$

\section{4}

Ouro Prêto se inclina com elegância,

Ouro Prêto se inclina, e um dia cairá.

Nova técnica transfigura a terra,

Mas os futuros engenheiros e arquitetos

Não mudarão o corpo de Ouro Prêto

Que ainda se preserva da reforma

Por sua mesma pobreza e solidão.

Ouro Prêto para o futuro um dia se voltará,

Gerando no seu bôjo a nova tradição...

Acelerando a história, a vida deslocou.

Mas a lenda combate aqui a história:

Seus espectros e igrejas permanecem

Pelo ciúme da morte resguardados.

Aqui o próprio Cristo, o rei da vida,

Que se diz Deus dos vivos, não dos mortos,

Aqui o mestre da ressurreição

É contemplado apenas em sua morte:

As tocantes Madonas são tocadas,

E o Senhor Morto, com ternura igual. ${ }^{10}$

Parece que em sua imensa humanidade

Aos espectros o Cristo se aparelha,

O seu ar familiar logo assumindo,

Abancado no largo das igrejas

Com os amigos, extrema assombração...

Aguardando seu próprio julgamento,

Sua caridade a todos estendendo,

Mesmo a Joaquim Silvério dá o pão.

\section{5}

Repousemos na pedra de Ouro Prêto,

Repousemos no centro de Ouro Prêto:

São Francisco de Assis! Igreja ilustre, acolhe,

À tua sombra irmã, meus membros lassos.

Confrontamos aqui tôda a miséria,

Da matéria o desgaste deduzindo

Em nossa vida universal e pessoal.

Ó rude tempo de aniquilamento,

Ó rude tempo de desproporção! ${ }^{11}$

Nem nos transforma a companhia do Anjo

Que, estendido no teto desta igreja,

Rumando para a terra, em vôo certeiro 
Despede ao chão a lâmpada de prata!

Entretanto êle é belo! Dançarino ${ }^{12}$

Do sôpro da saúde modelado,

Asas de larga envergadura tem,

E seus panejamentos apresenta

Com delicada graça, mas viril.

Respira o rosto, máquina rosada,

Um mesmo movimento aparelhando

A bôca, os olhos diurnos e o nariz;

Carnal vivência o busto manifesta,

Os cabelos castanhos esparzidos

Numa desordenada simetria

$O$ ritmo ajudam da composição;

Os pés calçados de sandálias gregas

Formam sólida base ao corpo inteiro.

Mas não se vale apenas de suas asas:

Os braços desenvoltos deslocando

O espaço em tôrno, rápido, oferecem

Flores, frutos da terra ao povo fiel.

Seus ornamentos sóbrios sintetizam

Do barroco mineiro a austera fôrça.

Assim o esculpiu na tradução humana

O escopro genial de Aleijadinho.

Mas de que serve a gratuidade do Anjo,

Que pode o Anjo ante a angustura do homem

E a fôrça da caveira desarmada

Que elevada se vê no tapa-vento?

Que pode o Anjo ante a manopla imóvel,

Ante a pátina da morte em Ouro Prêto?

Kyrie eleison. Memento mori. Kyrie eleison.

A primeira palavra utilizada no poema, "assombração", nos remete ao campo dos fantasmas, dos perecidos, daqueles que, ainda que não nos possam tocar, se projetam sobre nós (ou somos nós que os projetamos? Ou ambos lançam suas intocáveis projeções de si para si e de si para o outro? A via é de mão dupla), se fazem imagem para nós, e, via linguagem e montagem, se inscrevem. Além disso, a imagem que se oferece aos nossos olhos também consiste em montagem, anacrônica, de tempos heterogêneos. Os mortos retornam diferidos, a poesia os faz aqui em diferença, e o assomar parte do barroco, ou seja, da pervivência inscrita na ruína. Os mortos ganham alguma vida; uma espécie de still life latente está em cada um dos anjos e até mesmo nas portadas que são vistas por um sujeito presente-ausente que se afirma ao longo do discurso no vão de suas visões. Quem seriam esses mortos que vagam por Ouro Preto? Quais são as presenças espectrais que retornam no livro de Murilo?

Poderíamos apontar presenças de poetas, aqui associados também a padres loucos e reformadores. Ao longo da Contemplação de Ouro Preto, quem assom(br)a é Alphonsus de Guimaraens, também "contemplado" como um morto, mas morto pervivente, que passeia, como se põe no Acalanto, juntamente com Cláudio Manuel da Costa, por entre as ruínas. Vale lembrar que Alphonsus também é visitado por Mário de Andrade em Mariana, na viagem já referida de 1919, bem como por Drummond, em sua produção de fins de vida. Casam-se, em Murilo, o misticismo e a poesia de inspiração clássica, bem como a postura formadora do inconfidente; mistificação e nacional lado a lado em meados do século XX. Na hipertrofia do mineiro, salvaguarda-se o barroco da arquitetura como grande patrimônio, mas os antecedentes literários que o olhar encontra na cidade são árcades e simbolistas. Ao mesmo 
tempo em que aqui também temos, talvez, algum "seqüestro do barroco" na literatura, para retomar uma expressão de Haroldo de Campos, em nome do local, temos, por outro, a reivindicação de um momento político autonomista, qual seja, o da tentativa republicana da Inconfidência Mineira, cujo mártir, Tiradentes, aparece na segunda parte da Contemplação como aquele cujo grito não se ouve, e, em seguida, como quem recebe o pão de Cristo, mas o recebe em movimento da caridade incondicional daquele, e não com a dignidade do nobre que comunga em missa de domingo. Tiradentes é uma figura que se manifesta ainda, de certa forma, marginal, alma trágica e abandonada entre os ecos da cidade, espectro de revolução fracassada que ao mesmo tempo se reivindica, mas que serve como espelho da sorte que não se deseja na empreitada de "revolução" modernista.

O primeiro movimento do poema aparelha-se para a idéia da morte, que perpassa toda a composição; o cemitério ali é aéreo, ou seja, o depositário dos defuntos deixa de ser apenas as gavetas e passa a ser o ar onde o passado, incessante, se inscreve e pesa sobre os ombros de cada passante. "Tudo aparelha a mente para a morte / Mas a morte em si mesma, a própria morte, / Privada de artifício, a morte chã." Cada fragmento da cena solicita o eu incansavelmente, e seu olhar os justapõe, os cola, faz deles a montagem que faz desse poema também uma imagem, talvez um postal. A vida se adere à morte, incansavelmente: tudo afirma sua brevidade e vanidade, dizeres caros a Gregório de Matos, ou a Góngora. Permanecem os cacos. Ali estão as sombras das procissões, de tantos homens que já se foram, e, conseqüentemente, de tantos outros que, como o poeta, também passarão. Haverá legado além de cicatrizes, de ruínas em que pairam espectros à espera de alguma dicção, quiçá a do próprio poeta? A pedra se oferece marcada pelo tempo, tradutor: a repetição da cidade nos dizeres não pode se dar senão em diferença, mesmo se a inscrição é vaticinada pelo Estado. Resta aquilo que não se pode dizer: ao reconduzir os cacos a condições sempre cambiantes, a linguagem, esguia, trai. Retorna o silêncio, ele próprio significante, prenhe de dizeres na pedra muda.

A direção assumida na primeira parte é contrária à da dispersão das ossadas no tempo: é o amor da forma que repele a dispersão, que quer cristalizar, que quer fazer a pedra, o osso, o vestígio do morto tornar-se signo de identidade. A pedra é testemunho de um tempo, de uma origem como gênese importada, mas também de uma gênese que, conforme assinalava Mário de Andrade no fragmento já citado, é caracterizada pela diferença impressa pela contribuição brasileira: a pedra é aqui o alicerce de uma ficção do nacional. E ressurge no último verso da primeira parte como Pedra, maiúscula, pedra da lei, mas também Itacolomi, pedra dos bandeirantes, e se liga a um fundamento cristão, caro a Murilo desde sua conversão motivada pela morte de Ismael Nery. O fundamento bandeirante também é caro a Anhembi, já a partir do nome que a revista toma para si, e da missão que confessa ter: ser uma bandeira da alta cultura (e do alto modernismo) Brasil adentro e afora. E vão se tocando as matrizes modernistas. Pedra em que repousa a cabeça da Viúva; pedra da cidade, poema-pedra, prisma que prolifera significado para-além; aporia ele próprio no meio do caminho do Estado e da narração; leitura com e contra. A Promessa, também maiúscula, repele a dispersão do osso e da pedra: na escatologia temporal estabelecida, há uma salvação final, um futuro "melhor" para o qual se aponta em projeto, projétil.

A morte foi também tema caro a Rodrigo Mello Franco de Andrade, autor de Velórios, coletânea que é publicada em 1936, um ano antes de o autor assumir a diretoria do SPHAN e se afastar da criação literária. Cada um dos contos dessa coletânea é perpassado por algum falecimento, de motivo vário. Dona Guiomar, conto que abre o livro, narra a morte de uma viúva matriarca, mãe de um homem que tinha envolvimento com uma mulher "não muito digna", o que gerava desentendimentos familiares, em especial com o outro filho. É a esse outro filho que a morte da mãe surge como possibilidade de uma mudança de atitude por parte do irmão, para que este salvaguardasse algo em uma aristocracia decaída. O fenecimento da 
mãe acaba, assim, por lhe inspirar um lampejo de alegria, após um primeiro momento de tristeza no toque das mãos da morta. $\mathrm{O}$ toque do morto ressurge com a abjeção sentida pela esposa em $O$ enterro do seu Ernesto, a qual se recusava, em primeiro momento, a contemplar sequer o morto, cheia das falas em que alegava precisar preservar sua própria saúde (a morte do outro como inspiração do temor da própria morte). Depois de muita resistência, o beijo que dá no marido morto a põe em uma espécie de êxtase, em que se põe a falar sem cessar e a louvar o amor que sentia por aquele que pereceu.

Ora, não seria vedado pensar uma relação desse tipo com o grande cadáver de Ouro Preto? Como profanar esse sagrado cadáver? Talvez caiba mencionar, aqui, o Elogio da profanação, texto em que Agamben (2007, p.65-81) delineia reflexões precisas sobre o ato de profanar. Trata-se, pois, de restituir à esfera do uso, ao gozo, aquilo que dela foi apartado para destinar-se aos deuses (e aqui a relação entre religião e separação fica patente, de modo que toda separação, seja a para os deuses, seja a do cânone, seja a do poder, institui uma religião, antes releitura do que religação, para Agamben). As reflexões do italiano apontam para o fato de que se pode profanar tanto por contato (contágio) quanto por uso, por um jogo que seja capaz de tornar inativas as potências da economia, do direito e da política, convertendo-as na porta de uma nova felicidade. Seria, pois, uma forma de minar com o gozo a religião sem dogma do capitalismo, de culto permanente e direcionado à culpa em si, que instituiu a esfera do consumo e tornou o uso impossível pela imposição do fetiche, pela separação entre valor de uso e valor de troca. Lembro aqui que dois versos foram suprimidos por Murilo nas versões do poema subseqüentes à publicação em Anhembi: "As tocantes Madonas são tocadas, / E o Senhor Morto, com ternura igual." Murilo suprime, assim, o toque direto das imagens, a tatilidade do morto, o contágio do sagrado, a quarta dimensão da relação com essas imagens, o momento do gozo. Mas a pedra muda se oferece vincada; a marca mortuária não se apaga. E insiste em forçar o que quer se inscrever.

Com a segunda parte do poema, assomam sons no meio do silêncio. Cantos de igrejas, os sinos postos em uma sensação de tempo suspenso, os santos também espectrais em um clima carregadamente cristão, e talvez de alguma culpa cristã. $\mathrm{O}$ som informe dos sinos (carregado de significados pela religiosidade) encontra correspondência nas campainhas das mulas, remissão aos peregrinos. A pedra, aqui, é substituída pela vibração do som, que perpassa a matéria; ainda assim, essa informidade primeira ganha forma, ao também encontrar outra forma de correspondência na música dos pianos. Estes, explorados em outros pontos da poética muriliana, como no poema $O$ pastor pianista, em que surrealmente eles correm pelas planícies, tais como ovelhas, são tocados: não só deles sai música, mas o pastor (guia, condutor, como o músico clássico, dono de uma linguagem regrada e articulada) exercita sua tatilidade e, ainda, os toca, apascenta como rebanho. Dessa vez, os pianos são inconfidentes: seus sons ecoam pela cidade, ecoam pela tentativa liberal de configuração de um outro Brasil, que se gestou no âmago da Inconfidência Mineira. Pianos pastoreados por árcades, na diferença que produz a poética de Murilo? Vale lembrar que o inconfidente é aquele que não pode receber confidências: nos nós da sonoridade, a esfera do silêncio consegue espectralmente se fazer retornar.

Um terceiro movimento dos Motivos de Ouro Preto é o da perseguição da passante, ação moderna tão baudelaireana. Os passantes carregam aos ombros a morte, e surge, recoberta pelo luto, a figura instigante: a Viúva de Ouro Preto. A Viúva perdeu o marido ou a cidade, transformada, irreconhecível, com alguns cacos do passado inscritos? Recolhida em "uma toca de espectros rodeada", a viúva parece também insana: funde o que os outros consideram real com coisas do plano de seu imaginário, declara guerra sem que lhe seja investido poder para tanto, e tem uma vida que nada mais é do que trama de fantasmas que perecerão (ou não) junto com ela própria. Os fantasmas que mais assombram são os interiores. A viúva perdeu a riqueza, o marido, a cidade, e está entocada, como quis ficar o eu 
lírico de Os bens e o sangue, de Drummond ao se dirigir ao antepassado que não participou das barganhas. Vale destacar que o poema também foi publicado em Anhembi e depois se tornou parte de Claro enigma. Assim como a figuração vítima da decadência que assoma em Drummond, a viúva também é de grande família, e agora resta com os fantasmas da perda. A extinção do fenômeno está inscrita em sua origem, como já se disse a respeito das reflexões de Benjamin sobre o Trauerspiel (drama barroco alemão).

Na quarta parte, é a cidade em si, espécie de corpo morto-vivo, que ocupa o foco. A cidade se inclina, se curva com a elegância característica do tempo perdido, do alvorecer da corrida do ouro, e faz pressentir sua própria queda. A técnica (e aqui se inclua o projeto modernista de Lucio Costa, por exemplo, ou o processo de expansão que viveu a cidade no século $\mathrm{XX}$ ) pode rasurá-la, mas, para o sujeito que aqui fala, não é capaz de mudar seu corpo, sua carga plena dos espectros que em tanto a constituem. O passado é fantasma que não pode se ausentar. Algum passado é experiência no presente, se inscreve no olhar e intervém na ficcionalização do espaço. Entretanto, a cidade, nesse momento, se volta para o futuro, como mãe barroca de uma nova tradição, deslocada e ressignificada nos projetos modernistas. Em Murilo assoma um embate entre uma história dada e outra que grita (em silêncio), como lenda, por todos os cantos. A morte, ciumenta, aniquila e arrasta, mas não pode ou não quer apagar os rastros, as marcas que vetam à história, armação sobre cacos, uma só narrativa. $\mathrm{E}$ as lendas, insistindo em fugir, espectros como aqueles sobre os quais a cidade jaz, problematizam o próprio dizer a cidade, o próprio dizer.

A figuração cristã, tão marcante na poética de Murilo, nesse fragmento, é a de uma espécie de deus morto, que também não pôde fugir ao fluxo incessante da morte que contamina, mas não apaga: ele, como as madonas, é fundido em materialidade e corporeidade, é dobrado, des-obrado, se faz carne com espírito, se faz vestígio e fantasma, corpo e falta de corpo. Como imagem diferenciada, pode ser tocada sempre como morta, como signo de morte que sempre é uma imagem, como diferimento constante de si para consigo, como distância do referente, seqüestrado e intangível, aliado aos espectros e perfilado a Tiradentes. O mártir da cristandade é aqui posto ao lado de um herói nacional, que também ficou sozinho ao extremo na hora da morte. Mais do que isso: o morto-vivo Cristo compassivo, a imagem carnalizada dá o pão a um ideador condenado de nação: o Cristo sustenta a modernidade liberal. E aí não há mais contradição em uma aparição tão catolicamente difusa quanto a de Murilo em Anhembi. Porque se o cristianismo pode ser pai ou avô distante da modernidade, não há problema em figurar um Cristo que alimenta um projetista moderno de nação, espécie de mártir que se faz romântico para morrer tão só quanto. Ainda que o júri espere, e o julgamento, a deliberação e a perda pareçam tão implacáveis, estamos numa via barroca que imbrica as linhagens, problematiza as identidades, reconhece o que paira em torno dos ditos e dos constructos e aponta para um post.

O tempo em que se fala não é mais o tempo glorioso de Ouro Preto, mas sim o tempo em que o poeta, antes cantor das belezas pitorescas ou dos amores insondáveis, confronta a miséria sem mais poder fazer do que rogar de membros lassos. A quem? Aos santos, aos cristos e às madonas mortos, mortos-vivos, impotentes em um mundo em crise de deus e de quaisquer valores absolutos? O tempo em que se fala é o tempo de desgaste da matéria, é o tempo em que as coisas sólidas vão tomando posse de sua morte e, portanto, de sua vida, tempo que aniquila e em que alguns tentam desesperados salvar um patrimônio e salvaguardar-lhe um lugar de honra, como se passa com Anhembi e seu projeto de elevação da cultura na decadência do valor.

E eis que, ao fim de tudo, surge a figuração do Anjo, maiúsculo e enigmático, no teto da Igreja de São Francisco de Assis, a vigiar de cima e a se projetar na dobra de um movimento, a flechar e dardejar com alguma luz o sujeito que o contempla. A figura, sabe-se, é cara também ao raciocínio de Walter Benjamin: na Tese IX Sobre o conceito de história, o anjo é da história, e propelido é sem possibilidade de resistência para o futuro pela tempestade 
do progresso, tempestade advinda do paraíso que o faz rumar para o futuro ainda de costas para o passado, querendo despertar os mortos (BENJAMIN, in LÖWY, 2005, p.87). O anjo de Murilo, aqui, é belo, e a descrição das minúcias de seu aspecto barroco é larga, denotadora de fascínio: o anjo é vivo, respira, um movimento aparelha boca e nariz, e sua simetria desordenada faz uma composição ajustada pelo ritmo. A beleza do anjo seria (poderia ser) convulsiva, ao gosto bretoniano? $\mathrm{O}$ anjo desloca o espaço em volta, mas que podem seu ornamento e sua história diante da angústia de que tudo perece, de que os esforços se revelam vãos e de que uma morte sem redenção espreita por todos os cantos nas figuras que legou na cidade? O anjo do "escopro genial de Aleijadinho", o anjo que porta a luz, seria um anjo luciferino, que induz à busca de um saber que se encontra na base da conduta punível? Seria esse saber da razão a ameaça desse anjo, aquilo que no Trauerspiel Benjamin (2006, p. 453) chama de existência mais própria do mal? Seria a dádiva do anjo plena das promessas de Satã, das ilusões de liberdade, autonomia e infinitude?

Resta um lamento, em latim, de tom eclesiástico: "Kyrie eleison. Memento mori. Kyrie eleison". "Cristo, tende piedade. Lembre-se que você morrerá. Cristo, tende piedade". Invocações derradeiras que, em tom de coisa sagrada, levam a morte para além do (não-)lugar da cidade perdida e das ruínas de suas figuras assombrosas. Tudo perece. O leitor é tão mortal quanto o texto e o autor, e extinguir-se-á algum dia. E se o destino dessa Ouro Preto, desse patrimônio, dessa Minas e desse homem em Murilo não consegue fugir à destruição, se as promessas ou a ação do próprio anjo não os pudessem salvar, resta, após essa primeira circulação do poema que depois comporia e abriria o livro, finalizar este último com um Acalanto, dedicado a Guignard.

Dorme, Ouro Prêto reclusa,

Dorme, trágica Ouro Prêto,

Dorme, Ouro Prêto assombrada,

O sono da libertação. (MENDES, 1959, p. 445)

É interessante notar que Sérgio Milliet, crítico programático do pensamento em que se inscreve Anhembi, revista em que primeiro circulam os Motivos de Ouro Preto, pensa Murilo como um isolado pela pureza, talvez por uma pureza que a arte não devesse ter tão exacerbada para que pudesse restabelecer a comunicação com o público, por Milliet tão almejada. Mas, arte, ser em crise, não será essa sua saída ou seu fado? A arte do presente não será uma arte pensante? Os "devaneios surrealistas" de Murilo são lidos por Milliet como sublimação; o brado, como sintoma de máscara do complexo. "Se tudo falha, a vida, o amor, a solidariedade humana, talvez a realização ambicionada esteja em Deus. Mas Deus pode ser a miragem do próprio eu e ao correr ao encontro d'Êle é ao encontro de si mesmo que o poeta caminha." (MILLIET, 1951, p. 301) Esse deus de Murilo Mendes passaria, ao ver do crítico, a ser uma forma de sublimação ou de elevação de si, numa leitura de base psicanalítica que despreza a ficcionalidade do criado e entende a poesia como revelação de personalidade, mas revelação "em uma centelha" das "profundezas da alma". E a ficcionalidade do fazer poético? O "mito" por sob a "história"? A partir do reconhecimento de que "essa poesia é algo hermética, hostil à retórica, impenetrável à sensibilidade comum. Talvez fora do tempo e das ambições democráticas de nosso tempo" (ibid., loc. cit.), Milliet acaba por reconhecer a falta de lugar do espectral Murilo dentro de uma poética marginal que se quer configurar canônica, popular, lida e aceita pela sociedade. Mas o fecho que Milliet dá a seu texto deixa a fresta por onde as linhas voltam a se confundir. Porque, ainda que o poeta em questão assim se revele, o crítico sabe que "a lógica é uma mentira, um 'trompe d'oeil', uma ilusão puramente acadêmica, mas a verdade está: 'em outra posição, em outra dimensão'.” (ibid., p. 303) 


\footnotetext{
${ }^{1}$ A tradução deste e de outros excertos de Ranciére aqui citados é de minha responsabilidade.

${ }^{2}$ Devo esta observação à profa. Susana Scramim, a quem agradeço as indicações recebidas para a realização deste trabalho. Os agradecimentos são extensivos ao prof. Raúl Antelo, que fez várias indicações bibliográficas, e à profa. Maria Lucia de Barros Camargo, sob cuja orientação segue a pesquisa sobre a revista Anhembi, em que se inscreve este trabalho.

${ }^{3}$ Há que se lembrar o peso que uma crítica como Telê Porto Ancona Lopez dá ao Expressionismo na produção de Mário de Andrade. Mário possuía em sua biblioteca exemplares da revista Der Sturm; Telê aventa que teria saído daí a matriz de seu Amar, verbo intransitivo, e aventa mesmo a possibilidade de se ler Macunaíma como uma rapsódia expressionista. (Cf. LOPEZ, in SCHWARTZ, 1995, p. 375-380)

${ }^{4}$ A edição de 1954 introduz esta estrofação, não presente em Anhembi.

${ }^{5}$ Outra estrofação introduzida na edição de 1954.

6 "rejeitam", na edição dos poemas de Murilo pela Aguillar e em Poesias, organizado pelo próprio autor em 1959.

7 "é de grande família", a partir da edição de 1954. Parece ter havido uma troca, na impressão por Anhembi, do fim deste verso com o do último verso desta parte.

8 "A Viúva de Ouro Preto desce a rua rezando.", a partir da edição de 1954, conforme explicado na nota anterior.

${ }^{9} \mathrm{O}$ tempo verbal das outras edições não é o futuro do presente, mas o pretérito mais-que-perfeito.

${ }^{10}$ Este verso e o anterior não figuram nas edições posteriores.

${ }^{11}$ Apenas na edição da Nova Aguillar esse "Ó" introdutor de vocativo é substituído por um artigo. Tanto a revista como a edição de 1954 e a de Poesias, de 1959, mantêm o acento.

${ }^{12} \mathrm{O}$ aposto iniciado com "Dançarino" é introduzido por dois-pontos apenas na edição da Aguillar.
}

\section{REFERÊNCIAS}

AGAMBEN, Giorgio. Profanações. Trad. Selvino Assmann. São Paulo: Boitempo, 2007.

ANDRADE, Carlos Drummond de. Os bens e o sangue. Anhembi. v. I, n. 03. São Paulo: Anhembi, fev. 1951, p.465-469.

Claro enigma. 14. ed. Rio de Janeiro: Record, 2001.

ANDRADE, Mário de. A arte religiosa no Brasil. São Paulo: Experimento/Giordano, 1993.

BANDEIRA, Manuel. Guia de Ouro Preto. Rio de Janeiro: Ediouro, 2000.

BAUDELAIRE, Charles. As flores do mal. Trad. e notas de Ivan Junqueira. Rio de Janeiro: Nova Fronteira, 1985.

BENJAMIN, Walter. Obras escolhidas I: Magia e técnica, arte e política. Trad. Sérgio Paulo Rouanet; pref. Jeanne Marie Gagnebin. 7. ed. São Paulo: Brasiliense, 1994.

BENJAMIN, Walter. El origen del 'Trauerspiel' alemán. In.: . Obras. Libro I, vol. 1. Ed. de Rolf Tiedemann e Hermann Shweppenhäuser; trad. ao esp. de Alfredo Brotons Muñoz. Madrid: Abada, 2006.

CAMPOS, Haroldo de. O seqüestro do barroco na formação da literatura brasileira. Salvador: Fundação Casa de Jorge Amado, 1989.

CANTARINO, Carolina. Pesquisa explora dilemas entre tradição e modernidade em Ouro Preto. 23 dez. 2005. Disponível em: <http://www.revista.iphan.gov.br/materia.php?id=142>. 
Acesso em 29 jul. 2007.

DELEUZE, Gilles. Crítica e clínica. Trad. Peter Pál Pelbart. São Paulo: 34 Letras, 1997.

EINSTEIN, Carl. La escultura negra y otros escritos. Ed. a cargo de Liliane Meffre. Barcelona: Gustavo Gili SA, 2002.

GUIMARÃES, Júlio Castañon. Murilo Mendes: a invenção do contemporâneo. São Paulo: Brasiliense, 1986. (Série Encanto Radical.)

HOUAISS, Antonio; VILLAR, Mauro de Salles. Dicionário Houaiss da Língua Portuguesa. Rio de Janeiro: Objetiva, 2001.

LACERDA, Aline Lopes de. A Obra Getuliana: ou como as imagens comemoram o regime. Estudos Históricos, Rio de Janeiro, v. 7, n. 14, 1994.

LÖWY, Michael. Walter Benjamin: aviso de incêndio. Uma leitura das teses "Sobre o conceito de história.". Trad. Wanda Nogueira Caldeira Brant; trad. das teses por Jeanne Marie Gagnebin e Marcos Lutz Muller. São Paulo: Boitempo, 2005

MENDES, Murilo. Motivos de Ouro Prêto. Anhembi. v. II, n. 6. São Paulo: Anhembi, mai. 1951, p.487-491.

. Contemplação de Ouro Preto. Rio de Janeiro: Serviço de Documentação do Ministério da Educação e Cultura, 1954.

. Poesias (1925-1955). Rio de Janeiro: José Olympio, 1959.

. Poesia completa e prosa. Org., preparação do texto e notas por Luciana Stegagno-

Picchio. Rio de Janeiro: Nova Aguillar, 1997.

MILLIET, Sérgio. Dados para uma história da poesia modernista. II. Anhembi. v. I, n. 2. São Paulo: Anhembi, jan. 1951.

RANCIÉRE, Jacques. Politique de la littérature. Paris: Galilée, 2007.

SANTIAGO, Silviano. Nas malhas da letra. Rio de Janeiro: Rocco, 2002.

SCHWARTZ, Jorge. Vanguardas latino-americanas: polêmicas, manifestos e textos críticos. São Paulo: Edusp, 1995. 